\title{
HUBUNGAN OBESITAS DENGAN FAAL PARU PADA MAHASISWA FAKULTAS KEDOKTERAN UNIVERSITAS SAM RATULANGI MANADO
}

\author{
${ }^{1}$ Satriyani \\ ${ }^{2}$ Karel Pandelaki \\ ${ }^{2}$ M. C. P.Wongkar
}

\author{
${ }^{1}$ Kandidat Skripsi Fakultas Kedokteran Universitas Sam Ratulangi Manado \\ ${ }^{2}$ Bagian Ilmu Penyakit Dalam BLU RSU Prof. Dr. R. D. Kandou Manado \\ Email : satriyani11_036@yahoo.co.id
}

\begin{abstract}
Obesity is a multifactor disease as the result of excessive accumulation of fat tissues that affect the reduction of respiratory compliance. Change of respiratory function by obesity affect lungs function, i.e. Forced Vital Capacity (FVC) and Forced Expiratory Volume in First Second $\left(\mathrm{FEV}_{1}\right)$. The purpose of this research is to find out the correlation between Body Mass Index (BMI) and FVC and $\mathrm{FEV}_{1}$. This is a descriptive-analytic research with cross sectional method. Objects of the research were chosen with consecutive sampling technique. Subjects were 32 of Faculty of Medicine students, Sam Ratulangi University. FVC and FEV 1 were measured using spirometry. The correlation between BMI and FVC and $\mathrm{FEV}_{1}$ were tested using Pearson correlation test. FVC mean value at grade I obesity is $116,92 \%$ pred. FVC mean value at grade II obesity is $98,47 \%$ pred. FVC mean value at grade II obesity is lower than grade I obesity. FEV $\mathrm{Fean}_{1}$ value at grade I obesity is $118,23 \%$ pred. $\mathrm{FEV}_{1}$ mean value at grade II obesity is $107,16 \%$ pred. FEV1 mean value at grade II obesity is lower than grade I obesity. There is an insignificant negative correlation between FVC $(r=-0,343 ; p=0,054)$ and $\mathrm{FEV}_{1}(\mathrm{r}=-0,297 ; \mathrm{p}=0$,099). Conclusion: Increase in BMI can lower the lungs function, i.e. $\mathrm{FVC}$ and $\mathrm{FEV}_{1}$.
\end{abstract}

Keywords: FVC, $\mathrm{FEV}_{1}$, obesity

\begin{abstract}
Abstrak: Obesitas merupakan suatu penyakit multifaktorial, yang terjadi akibat akumulasi jaringan lemak berlebihan, sehingga menurunkan compliance sistem pernafasan. Perubahan fungsi pernafasan akibat obesitas mempengaruhi nilai fungsi paru diantaranya Kapasitas Vitas Paksa(KVP) dan Volume Ekspirasi Paksa Detik Pertama(VEP ${ }_{1}$ ). Penelitian ini bertujuan untuk mengetahui hubungan Indeks Massa Tubuh dengan KVP dan $\mathrm{VEP}_{1}$. Penelitian ini bersifat deskriptif analitik dengan pendekatan cross sectional. Teknik pengambilan sampel yang digunakan yaitu consecutive sampling. Subyek penelitian adalah mahasiswa Fakultas Kedokteran Universitas Sam Ratulangi dengan jumlah 32 subyek. KVP dan VEP $_{1}$ diukur dengan menggunakan spirometer. Nilai mean KVP pada obese I ialah 116,92\% pred, KVP obese II ialah $98,47 \%$ pred. Nilai mean KVP obese II 18,45\% lebih rendah daripada obese I. Nilai mean $\mathrm{VEP}_{1}$ pada obese I ialah $118,23 \%$ pred, $\mathrm{VEP}_{1}$ obese II ialah $107,16 \%$ pred. Nilai mean $\mathrm{VEP}_{1}$ obese II $11,07 \%$ lebih rendah daripada obese I. Hubungan IMT dengan KVP dan $\mathrm{VEP}_{1}$ diuji dengan menggunakan uji korelasi pearson. Terdapat hubungan negatif non signifikan antara IMT dengan KVP $(r=-0,343 ; p=0,054)$ dan $\operatorname{VEP}_{1}(r=-0,297 ; p=0,099)$. Simpulan: Peningkatan Indeks Massa Tubuh dapat menurunkan nilai fungsi paru diantaranya KVP dan VEP

Kata Kunci: KVP, VEP 1 , obesitas
\end{abstract}


Kecenderungan terjadinya obesitas berhubungan erat dengan pola makan. Obesitas terjadi karena ketidakseimbangan antara energi yang masuk dengan energi yang keluar. ${ }^{1}$ World Health Organization (WHO) tahun 2008 memperkirakan lebih dari 1,4 miliar orang dewasa mengalami kelebihan berat badan, dari orang dewasa yang mengalami kelebihan berat badan, lebih dari 200 juta pria dan hampir 300 juta wanita mengalami obesitas. ${ }^{2}$ Data Center for Disease Control and Prevention (CDC) tahun 2010, sebesar $14 \%$ dari orang dewasa Amerika Serikat dengan IMT 3035, $14 \%$ IMT 35-40 dan IMT > 40 sebanyak $6 \%{ }^{3}$ Menurut RISKESDAS 2013, prevalensi obesitas secara nasional adalah $19,7 \%$ dengan prevalensi penduduk obesitas terendah di provinsi Nusa tenggara Timur (6,2\%) dan tertinggi di Sulawesi Utara $(24,0 \%)^{4}$

Indeks Massa Tubuh (IMT) diukur berdasarkan rumus :

$$
\mathrm{IMT}=\mathrm{BB}(\mathrm{kg}) / \mathrm{TB}(\mathrm{m})^{2}
$$

Obesitas merupakan faktor resiko mayor terhadap penyakit kardiovaskular beberapa jenis kanker serta diabetes melitus tipe 2. Selain itu, dalam beberapa penelitian diketahui juga bahwa obesitas berhubungan dengan berbagai gangguan pernapasan antara lain tahanan aliran udara, pola pernapasan, pertukaran gas,mekanika pernapasan dan akhirnya akan mengakibatkan keabnormalitasan dalam tes fungsi paru. ${ }^{5}$ Perubahan karakteristik pada obesitas yang dapat dicatat pada sistem mekanik pernafasan yaitu adanya jaringan adiposa di sekitar tulang rusuk, abdomen, dan rongga viseral yang mengisi dinding dada mengakibatkan tekanan intraabdominal meningkat, menurunkan volume paru akhir ekspirasi, compliance dinding dada menurun, kerja pernafasan meningkat yang pada dasarnnya disebabkan adanya penurunan pada volume residu ekspirasi, kapasitas vital dan kapasitas total paru. ${ }^{6-7}$

\section{METODE PENELITIAN}

$\begin{array}{lcr}\text { Jenis penelitian yang dilakukan } \\ \text { bersifat deskriptif analitik } & \text { dengan } \\ \text { pendekatan cross sectional. } & \text { Jadwal } \\ \text { penelitian dilaksanakan pada } & \text { bulan }\end{array}$ November-Desember 2015. Populasi penelitian adalah mahasiswa Fakultas Kedokteran UNSRAT. Sampel penelitian diambil dari populasi yang memenuhi kriteria inklusi dan eksklusi. Kriteria inklusi meliputi mahasiswa Fakultas Kedokteran UNSRAT berusia 18-25 tahun, dan IMT $\geq 25 \mathrm{~kg} / \mathrm{m}^{2}$. Kriteria eksklusi meliputi subyek menolak berpartisipasi, ada riwayat penyakit paru, mahasiswa yang merokok dan memiliki kelainan dinding dada. Sampel penelitian berjumlah 32 orang serta dipilih dengan cara consecutive sampling.Variabel yang digunakan untuk variabel bebas Indeks Massa Tubuh dan variabel terikat Kapasitas Vital Paksa(KVP) dan Volume Ekspirasi Paksa Detik Pertama.

Alat yang digunakan meliputi spirometer, timbangan, mikrotoise. Persiapan penelitian yaitu penandatangan informed consent oleh responden yang telah memenuhi kriteria inklusi. Wawancara dengan menggunakan kuesioner untuk diisi oleh responden yang telah memenuhi kriteria inklusi. Subyek dikumpulkan kemudian dilakukan penimbangan berat badan dan pengukuran tinggi badan.

Pemeriksaan dilakukan dengan menggunakan alat spirometer. Cek kesiapan alat spirometri dan lakukan kalibrasi setiap sebelum digunakan. Masukkan data mengenai identitas subyek seperti nama, umur, jenis kelamin, tinggi badan dan berat badan ke dalam spirometer. Subyek dalam posisi berdiri. Pasien diinstruksikan memakai nose clip. Mouthpiece dimasukkan dalam mulut. Subyek menarik nafas kemudian nafas dihembuskan dalam mouthpiece dengan kekuatan yang maksimal.

Analisis bivariat dilakukan untuk melihat hubungan antara IMT dengan KVP dan $\mathrm{VEP}_{1}$ menggunakan analisis pearson. 


\section{HASIL PENELITIAN}

Penelitian ini dilakukan di Poliklinik paru RSUP Prof. Dr. R. D. Kandou dari bulan November- Desember 2014. Sampel dipilih dengan metode consecutive sampling yang berjumlah 32 orang. Berdasarkan jenis kelamin (tabel 1), sampel penelitian laki-laki sebanyak 22 orang (68,8\%) dan perempuan 10 orang (31,2\%). Sampel pada penelitian dibagi menjadi obesitas I dan II (tabel 2) dengan jumlah obesitas I 13 orang $(40,6)$ dan obesitas II 19 orang $(59,4 \%)$

Tabel 1. Distribusi Subyek berdasarkan jenis kelamin

\begin{tabular}{lcc}
\hline Jenis Kelamin & $\mathrm{N}$ & $\%$ \\
& & \\
\hline Laki-laki & 22 & 68,8 \\
Perempuan & 10 & 31,2 \\
\hline Total & 32 & 100 \\
\hline
\end{tabular}

Tabel 2. Distribusi Subyek berdasarkan derajat obesitas

\begin{tabular}{lll}
\hline Derajat Obesitas & $\mathrm{N}$ & $\%$ \\
& & \\
\hline Obesitas I & 13 & 40,6 \\
Obesitas II & 19 & 59,4 \\
\hline Total & 32 & 100 \\
\hline
\end{tabular}

Tabel 3. Nilai Mean, Minimum dan Maksimum Obesitas

\begin{tabular}{lcc}
\hline & Mean & Min-Max \\
& & \\
\hline Umur & 19,18 & $18-22$ \\
Obesitas I & 28,01 & $25,60-29,98$ \\
Obesitas II & 33,61 & $30,12-38,69$ \\
KVP obese I & 116,92 & $92-145$ \\
KVP obese II & 98,47 & $67-130$ \\
VEP $_{1}$ obese I & 118,23 & $88-139$ \\
VEP $_{1}$ obese II & 107,16 & $86-132$ \\
\hline
\end{tabular}

Tabel 4. Kategori Faal Paru Berdasarkan Nilai KVP dan $\mathrm{VEP}_{1}$

\begin{tabular}{lcc}
$\begin{array}{l}\text { Nilai KVP } \\
\text { dan VEP }\end{array}$ & N & $\%$ \\
\hline Normal & 25 & 78,1 \\
Restriktif & 7 & 21,9 \\
Obstruktif & 0 & 0 \\
\hline Total & 32 & 100 \\
\hline
\end{tabular}

Berdasarkan Tabel 2, ditemukan 7 subyek $(21,9)$ tergolong restriktif dan 25 $(78,1)$ subyek tergolong normal.

Gambar 1. Hubungan IMT dengan KVP

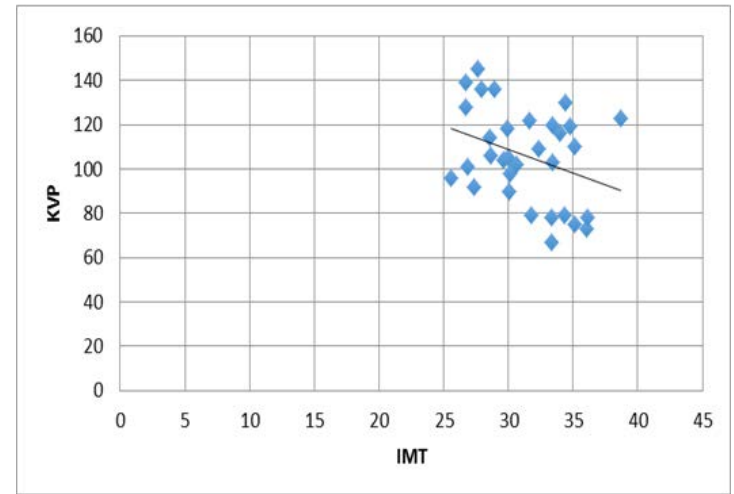

Hasil uji statistik dengan menggunakan Pearson Correlation diperoleh nilai $r$ sebesar -0,343 dengan tingkat signifikansi $\mathrm{p}=0,054$. Nilai korelasi $\mathrm{r}$ menggambarkan tingkat kekuatan hubungan antara dua variabel yaitu variabel bebas (IMT) dengan variabel terikat (KVP). Nilai korelasi yang diperoleh adalah $r=-0,343$ yaitu tingkat kekuatan hubungannya bersifat negative lemah. Nilai signifikansi penelitian diperoleh nilai $\mathrm{p}=0,054$, apabila dibandingkan dengan nilai $\alpha=5 \%(0,05)$, maka $\mathrm{p}>0,05(0,054>0,05)$, sehingga dapat disimpulkan bahwa antara variabel bebas (IMT) tidak mempunyai hubungan yang signifikan dengan variabel terikat (KVP). 
Gambar 2. Hubungan IMT dengan $\operatorname{VEP}_{1}$

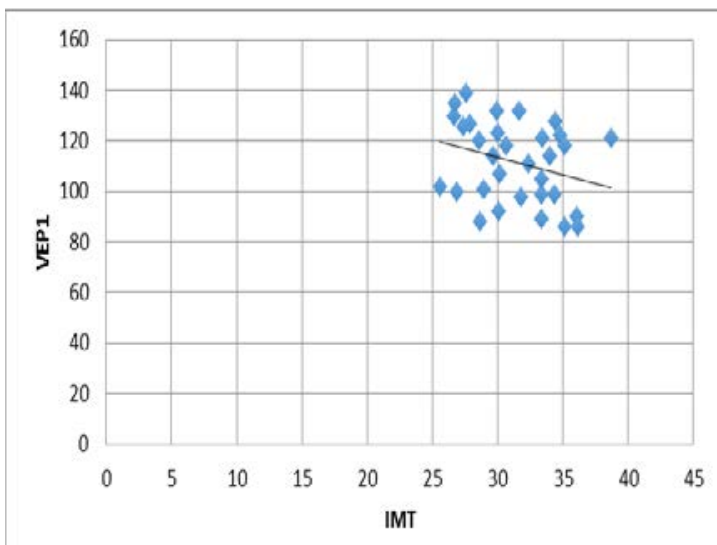

Hasil uji statistik dengan menggunakan Pearson Correlation diperoleh nilai $r$ sebesar -0,297 dengan tingkat signifikansi $\mathrm{p}=0,099$. Nilai korelasi $\mathrm{r}$ menggambarkan tingkat kekuatan hubungan antara dua variabel yaitu variabel bebas (IMT) dengan variabel terikat (VEP1). Nilai korelasi yang diperoleh adalah $\mathrm{r}=-0,297$ yaitu tingkat kekuatan hubungannya bersifat korelasi negative lemah. Nilai signifikansi penelitian diperoleh nilai $\mathrm{p}=0,099$, apabila dibandingkan dengan nilai $\alpha=5 \%(0,05)$, maka $\mathrm{p}>0,05(0,099>0,05)$, sehingga dapat disimpulkan bahwa antara variabel bebas (IMT) tidak mempunyai hubungan yang signifikan dengan variabel terikat $\left(\mathrm{VEP}_{1}\right)$.

\section{BAHASAN}

Karakteristik subyek pada tabel 1 menunjukkan bahwa bahwa rata-rata (mean) KVP pada obesitas I dan II berturut- turut ialah 116,92 dan 98,47 dimana terdapat perberaan nilai mean antara obesitas I dan obesitas II, dengan nilai mean obesitas II lebih rendah dari pada obesitas I sesuai dengan teori yang mengatakan bahwa kapasitas paru akan menurun seiring dengan bertambahnya $\mathrm{IMT}^{6-8}$. Hal yang sama terdapat pada nilai mean VEP1 pada obesitas I yaitu 118,23 dan obese II yaitu 107,16 dimana nilai mean pada obesitas II lebih rendah dari pada obesitas I.

Pada penelitian ini ditemukan 21,9\% subyek yang mengalami kelainan paru restriktif dan tidak ada yang tergolong obstruktif sesuai dengan penelitian yang dilakukan oleh Zammit $\mathrm{dkk}^{8}$ menyatakan bahwa hubungan antara bertambahnya IMT dan berkurangnya KVP lebih bermakna dibanding VEP1. VEP1 berkurang dengan kecepatan jauh lebih lambat dibanding KVP, sehingga obesitas lebih sering dihubungkan dengan penyakit paru restriktif dari pada obstruktif.

Berhadasarkan hasil analisis pearson, didapatkan bahwa tidak terdapat hubungan yang signifikan antara IMT dengan KVP (Gambar 1). Hasil yang didapatkan berbeda dengan penelitian yang dilakukan oleh Lolo $\mathrm{JL}^{9}$ dan Zerah $\mathrm{F}$ dkk ${ }^{10}$ yang menyatakan bahwa terdapat hubungan yang signifikan antara IMT dengan KVP. Meskipun penelitian ini secara statistik tidak memiliki hubungan yang signifikan, namun apabila dilihat dari nilai rata-rata KVP pada obesitas II lebih rendah daripada obesitas I yang menunjukkan bahwa semakin bertambahnya indeks massa tubuh, maka nilai KVP juga semakin menurun, terlihat dari nilai korelasi yang diperoleh yakni 0,343. Tanda (-) menunjukkan arah yang berlawanan. Perbedaan ini mungkin disebabkan oleh nilai rata-rata usia reseponden. Nilai rata-rata usia responden pada penelitian yang di lakukan oleh Lolo $\mathrm{J}$ $\mathrm{L}^{9}$ yaitu 40,2 tahun, penelitian yang dilakukan oleh Zerah $\mathrm{F}^{10}$ yaitu 38,7 tahun sedangkan pada penelitian in 19 tahun. Hal ini didukung oleh penelitian yangdilakukan oleh Pruthi N dan Multani $\mathrm{NK}^{11}$ dan penelitian yang dilakukan oleh Behera AA $\mathrm{dkk}^{12}$ yang mengatakan bahwa fungsi paru menurun secara signifikan seiring dengan bertambahnya usia. Hubungan antara IMT dangan $\mathrm{VEP}_{1}$ (Gambar 2) juga didapatkan hasil yang tidak signifikan, meskipun penelitian ini secara statistik tidak memiliki hubungan yang signifikan, yang berlawanan. Jika IMT meningkat, VEP1 menurun. Hasil penelitian ini sama dengan penlitian yang dilakukan oleh Lolo $\mathrm{JL}^{9}$ yang mengatakan bahwa tidak terdapat hubungan yang signifikan antara IMT dengan

VEP1. 


\section{SIMPULAN}

Berdasarkan hasil penelitian dapat disimpulkan terdapat hubungan negatif antara IMT dan KVP serta $\mathrm{VEP}_{1}$ pada mahasiswa obese Fakultas Kedokteran Universitas Sam Ratulangi Manado dengan nilai korelasi pearson berturut-turut $\mathrm{r}=$ 0,343 dan $r=-0,297$, namun secara statistik tidak bermakna.

\section{DAFTAR PUSTAKA}

1. Sugondo S. Obesitas. Dalam : Sudoyo AW, Setiyohadi B, Alwi I, Simadibrata KM, Setiati S. Buku Ajar Ilmu Penyakit Dalam Jilid III. Edisi ke-5. Jakarta: Interna Publishing; 2009.h.1919-20.

2. World Health Organization. Media centre. Fact Sheets. Obesity and Overwight. Agustus 2014 [ diakses tanggal : 28 September 2014] Tersedia dari : http://www.who.int/mediacentre/factsh eets/fs311/en/

3. Centers for Disease Control and Prevention (CDC). Healthy Weight: About BMI for Adults. 2010.

4. Ristianingrum I, Rahmawati I, Rutijo L. Hubungan antara Indeks Massa Tubuh dengan Tes Fungsi Paru. Mandala of Health. 2010;4:105.
5. Salome CM, King GG, Berend N. Physiology of Obesity and Effect on Lung Function. J Appl Physiol. 2010;108:206-11.

6. Pedoto A. Lung Physiology and Obesity: Anesthetic Implications for Thoracic Procedures. Anesthesiology. 2012:1-2.

7. Zammit et al. Obesity and Respiratory Diseases. International Journal of General Medicine. 2010;3:335-43.

8. Lolo JL. Hubungan kelebihan Berat Badan dengan Faal Paru. [Tesis]. [Semarang]: Fakultas Kedokteran Universitas Diponegoro.

9. Zerah F, Alain H, Leon P, Hubert, AnnML, Guy A. 1993. Effects Of Obesity on Respiratory Resistance. American College of Chest Physicians atau Chest Journal. 103:1470-76.

10.Pruthi N, Multani NK. Influence of Age on Lung Fuction Test. Journal of Exercise Science and Physiotherapy. 2012;8:1-6.

11.Behera AA, Behera BK, Dash S, Mishra S. Variation of Pulmonary Function Tests with Relation to Increasing Age in Healthy Adults. International Journal of Health Sciences and Research. 2014;4:136-41. 